Acta Protozool. (2017) 56: 289-301

www.ejournals.eu/Acta-Protozoologica

doi:10.4467/16890027AP.17.025.7827

PROTOZOOLOGICA

\title{
The Impacts of Crustacean Zooplankton on a Natural Ciliate Community: a Short-term Incubation Experiment
}

\author{
Jing LI' ${ }^{1}$, Kun YANG ${ }^{1}$, Feizhou CHEN² , Wenxuan LU ${ }^{1}$, Ting FANG ${ }^{1}$, Xiuxia ZHAO ${ }^{1}$, Haiyang LI', \\ Kai CUI ${ }^{1}$
}

${ }^{1}$ Fisheries Research Institute, Anhui Academy of Agricultural Sciences, Hefei, China; ${ }^{2}$ State Key Laboratory of Lake Science and Environment, Nanjing Institute of Geography and Limnology, Chinese Academy of Sciences, Nanjing, China

\begin{abstract}
Direct and indirect effects of crustacean zooplankton (cladocerans and copepods) are important regulators of ciliate communities, especially in eutrophic systems. However, it is not clear whether pseudodiaptomids (e.g., Schmackeria), one of the dominant calanoid copepods in Chinese lakes, effectively impacts natural ciliate communities. The impacts of small-bodied cladocerans (e.g., Bosmina) on ciliates are also controversial.

We performed an incubation experiment using winter lake water from Lake Chaohu to assess the structuring effects that crustacean zooplankton have on natural ciliate populations. The presence and absence of cladocerans (Bosmina sp.) and copepods (Schmackeria inopinus) were alternated in four treatments.

Both Bosmina sp. and Schmackeria inopinus had substantial impacts on ciliate abundance, biomass, and community structure. The response of ciliates was different in the presence of Bosmina sp. compared with Schmackeria inopinus and varied among categories such as the ciliate population, relative body size and functional feeding group. Our results also highlight the importance of interference and exploitative competition among metazooplankton groups.
\end{abstract}

Key words: ciliates, small-bodied cladocerans, pseudodiaptomid copepods, suppression impacts, functional groups

\section{INTRODUCTION}

Protozoa, especially ciliates, effectively utilize the production of bacteria and phytoplankton and may play an important role in transferring energy and materials from their prey to larger zooplankton (e.g., Weisse and Scheffel-Möser 1990; Zubkov and Leakey 2009).

Address for correspondence: Kai Cui, Fisheries Research Institute, Anhui Academy of Agricultural Sciences, NO. 40 South Nongke Road, Luyang District, Hefei, Anhui, China; Fax: +86 551 65147122; E-mail: LJLJ278@126.com
Genera belonging to Oligotrichida (e.g., Rimostrombidium and Hateria), Prostomatida (e.g., Balanion and Urotricha), Scuticociliatida (e.g., Cyclidium), and Peritrichida (e.g., Vorticella) typically dominate planktonic ciliate communities in eutrophic Chinese lakes ( $\mathrm{Li}$ et al. 2013, 2014, 2016). Species dominance and total ciliate abundance are determined by different factors in lakes (van Wichelen et al. 2013). In eutrophic freshwater ecosystems, food resources (bottom-up effect) for ciliates are relatively plentiful; thus, predator-mediated (top-down) effects are vital to the ciliate communities (Sanders and Wickham 1993; Burns and Schallenberg 2001; Galbraith and Burns 2010; Agasild et al. 2013). 
Crustacean zooplankton (copepods and cladocerans) can potentially impact ciliate assemblages through direct predation and (or) exploitative and interference competition (see reviews, e.g., Sanders and Wickham 1993; Jürgens 1994; Jack and Gilbert 1997). Relationships between copepods and ciliates have been widely studied in both freshwater lakes and marine environments (e.g., Hansen 2000; Zöllner et al. 2009; Dhanker et al. 2013; Rollwagen-Bollens et al. 2013). It has been shown that the predation rate of copepods on ciliates is high (Adrian and Schneider-Olt 1999; Burns and Gilbert 1993; Kamjunke et al. 2012) and that predation by both cyclopoid (e.g., Cyclops, Diacyclops, and Thermocyclops) and calanoid copepods (e.g., Boeckella, Epischura, Eudiaptomus, and Diaptomus) can strongly influence the abundance, biomass, and species composition of ciliates (Wiackowski et al. 1994; Wickham 1998; Adrian and Schneider-Olt 1999; Hansen 2000; Balseiro et al. 2001). Although many species are capable of grazing on ciliates, it is not clear whether pseudodiaptomids (e.g., Schmackeria), one of dominant calanoid copepods in Chinese lakes, can cause significant impacts on ciliate populations. Both large (e.g., Daphnia pulex) and intermediate-sized daphnids (e.g., Daphnia galeata mendotae) are known to suppress ciliate assemblages (Gilbert 1989; Wickham and Gilbert 1991; Jürgens 1994), but the impacts of small-bodied cladocerans (e.g., Bosmina, Chydorus) on ciliates are controversial (Wickham and Gilbert 1991; Ventelä et al. 2002; Agasild et al. 2012).

The effects of crustacean zooplankton on ciliates are dependent on the species and both the grazer and prey sizes (e.g., Burns and Gilbert 1993; Jack and Gilbert 1993; Adrian and Schneider-Olt 1999; Agasild et al. 2012). Copepod clearance rates were higher on oligotrichs than other ciliates species (Burns and Gilbert 1993; Hansen 2000). The ciliate ingestion rates of several common species of both copepods (e.g., Eudiaptomus graciloides, Diacyclops bicuspidatus, and Thermocyclops oithonoides) and Daphnia (e.g., Daphnia hyalina and Daphnia cucullata) were always higher for ciliates in the 20-55 $\mu \mathrm{m}$ size category than for smaller ciliate species $(10-20 \mu \mathrm{m})$ (Adrian and Schneider-Olt 1999). The abundance of grazers is also a key factor (Burns and Gilbert 1993; Burns and Schallenberg 1996). For example, the growth of oligotrich (Strobilidium velox) (ca. $43 \mu \mathrm{m}$ ) populations was halted by the presence of approximately 1.6 adult Epischura $\mathrm{L}^{-1}$ or sixteen adult female Diaptomus $\mathrm{L}^{-1}$ in summer (Burns and Gilbert 1993).
In the present study, we performed an incubation (15 days) experiment and manipulated the presence and absence of both Bosmina sp. and Schmackeria inopinus to test (1) whether small cladocerans (Bosmina sp.) and a pseudodiaptomid copepod (Schmackeria inopinus) effectively impact natural winter ciliate communities and (2) how the ciliates, at species and community levels, respond to the presence of crustacean zooplankton groups.

\section{MATERIALS AND METHODS}

\section{Study site}

Lake Chaohu $\left(31^{\circ} 25^{\prime}-31^{\circ} 43^{\prime} \mathrm{N}, 117^{\circ} 16^{\prime}-117^{\circ} 5^{\prime} \mathrm{E}\right)$ is a semiclosed (artificially controlled), shallow, eutrophic lake situated in eastern China. The lake has an area of $770 \mathrm{~km}^{2}$, a mean depth of $2.7 \mathrm{~m}$ and a maximum depth of $3.8 \mathrm{~m}$. Submerged vegetation is sparse. Cyanobacterial blooms first appeared in the 1950s and have occurred in the lake every summer and autumn since the 1980s. The monthly mean total phytoplankton biomass varies between 5.05 and $19.70 \mathrm{mg} \mathrm{L}^{-1}$, and bacillariophytes (mainly Melosira, Cyclotella, Synedra, and Surirella) and cyanophytes (mainly Anabaena and Microcystis) dominate the winter algal assemblages compared with the other seasons (Deng et al. 2007). The cladoceran community is dominated by Daphnia spp. in spring and by small-sized Bosmina coregoni in summer, autumn, and winter. Limnoithona sinensis, Sinocalanus dorri and Schmackeria inopinus are the main species of copepods (Deng et al. 2008). The mean ciliate abundance was 27.5, 13.4, and 5.6 cells $\mathrm{mL}^{-1}$ in July 2009, December 2009, and April 2010, respectively (Li et al. 2013). The ciliate communities were dominated by small-bodied species, e.g., oligotrich Rimostrombidium brachykinetum, prostomatids Balanion planctonicum and Urotricha farcta, and scuticociliatid Cyclidium spp.

\section{Experimental design}

The incubation experiment was conducted to assess the impacts of cladocerans and copepods on natural ciliate communities. Lake water from a depth of $0.5-1 \mathrm{~m}$ was collected from Lake Chaohu (N31 $\left.38^{\prime} 20^{\prime \prime}, \mathrm{E} 117^{\circ} 22^{\prime} 18^{\prime \prime}\right)$ on 24 December 2013 with a Patalas sampler (5 L). A qualitative zooplankton sample was collected using a zooplankton net $(64 \mu \mathrm{m})$ at the same site. Lake water and zooplankton were stored in plastic carboys and transported to the laboratory as soon as possible, which is ca. $28 \mathrm{~km}$ away from Lake Chaohu. At the sampled site, the water temperature was $5.5^{\circ} \mathrm{C}$, the Secchi depth was $55 \mathrm{~cm}$, the dissolved oxygen was $8.49 \mathrm{mg} \mathrm{L}^{-1}$, the $\mathrm{pH}$ was 8.4 , and the chlorophyll a was $21.2 \mu \mathrm{g} \mathrm{L}^{-1}$. The total suspended solids, the total nitrogen and the total phosphorus concentrations were $30.5,3.7$ and $0.17 \mathrm{mg} \mathrm{L}^{-1}$, respectively.

Four treatments were set and named FILTER, CONTROL, CLAD and COPE. Each treatment was triplicated. The CONTROL treatment contained natural lake water with both cladocerans and copepods. The lake water was preliminarily filtered through the zooplankton net $(64 \mu \mathrm{m})$ in the other three treatments. Neither cladocerans nor copepods were added to the FILTER treatment; 
additionally, only cladocerans (Bosmina sp.) were added to the CLAD treatment and only copepods (Schmackeria inopinus) were added to the COPE treatment. Both Bosmina sp. and S. inopinus were selected from the qualitative sample using a stereoscopic microscope (Olympus SZX10, Tokyo, Japan) in the laboratory (ca. $5^{\circ} \mathrm{C}$ ). Active animals were selected and put into 1-L beakers with filtered $(64-\mu \mathrm{m}$ net) lake water. Then, the beakers containing the water and the selected animals were placed into containers corresponding to each appropriate treatment. In CLAD and COPE treatments, the abundances of added Bosmina sp. and S. inopinus were the same as the corresponding abundances in lake water (Table 1). All the containers with $5 \mathrm{~L}$ of water were incubated in an uncovered cement pond $(1 \mathrm{~m}$ in depth and $3 \times 3 \mathrm{~m}$ square $)$ near the laboratory, approximately $30 \mathrm{~cm}$ below the surface. The experimental treatments were set up within $4 \mathrm{~h}$ from when the collected samples arrived at the laboratory. The experiment began on $25 \mathrm{De}-$ cember 2013 and lasted for 15 days.

\section{Biological sampling and analysis}

Samples $(200 \mathrm{~mL})$ for analysing phytoplankton were taken separately from each container on days 1 and 15 and fixed with acid Lugol's solution (final concentration 1.5\%). Ciliate samples $(200 \mathrm{~mL})$ were collected separately from each container on days $1,5,10$, and 15 and fixed with Bouin's solution (final concentration 5\%). Samples were then concentrated from $200 \mathrm{~mL}$ to $50 \mathrm{~mL}$ by settling prior to further analysis. Algal cells were identified, enumerated and measured with a microscope (Olympus BX53, Tokyo, Japan) at $400 \times$ magnification in 0.1-mL counting chambers ( $\mathrm{Hu}$ and Wei, 2006). Ciliate samples were manipulated separately using the quantitative protargol staining (QPS) approach (Skibbe 1994; Li et al. 2013). Ciliate species identification was based on Kahl (1930-1935), Corliss (1979), Foissner and Berger (1996), Foissner et al. (1999), and Lynn (2008), while biomass (as wet weight) calculation referred to the literature (e.g., Foissner et al. 1999).

Metazooplankton screened (64- $\mu \mathrm{m}$ mesh) from $10 \mathrm{~L}$ of lake water were preserved and used as the abundance estimates of cladocerans, copepods, and rotifers allocated to containers on day 1. On the last day, the metazooplankton samples were collected separately from each container by pouring all of the water through a $64-\mu \mathrm{m}-$ mesh nylon net. Metazooplankton samples were preserved in $40 \%$ formaldehyde, for a final concentration of $2 \%(\mathrm{v} / \mathrm{v})$, and measured and analysed with a light microscope (Olympus BX53; Japan) at $100 \times$ magnification. The identification keys for cladocerans, copepods, and rotifers were from Chiang and Du (1979), Sheng (1979), and Wang (1961), respectively. The biomass of rotifers and crustacean plankton was estimated according to Huang et al. (2000).

\section{Data analysis}

The normality and homogeneity of the variables were tested with the Shapiro-Wilk test and Levene's test, respectively, using the IBM SPSS Statistics package (SPSS 19.0). Several variables (abundance of mixotrophs, Askenasia chlorelligera and Tintinnidium pusillum and biomass of prostomatids, algae, and rotifers) showed slight heterogeneity that we were unable to correct with transformations; thus, results should be considered with caution. Repeatedmeasures ANOVA (GLM procedure in the SPSS Statistics package) was used to test the differences among the treatments and the variance over time for the abundance and biomass of algae and ciliate groups (total ciliates, each ciliate species, small ciliates, medium ciliates, large ciliates, oligotrichs, prostomatids, algivores, bacterivores, mixotrophs, total algae, cyanophytes, bacillariophytes, and chlorophytes). Differences in rotifers among treatments were tested with one-way ANOVA. The significance level (further referred to as " $P_{a d j}$ ") was corrected using the Bonferroni technique (Rice 1989).

\section{RESULTS}

\section{Dynamics of phytoplankton and metazooplankton}

The algal assemblages were initially dominated by cyanophytes (mainly Microcystis and Anabaena) and finally by bacillariophytes (e.g., Cyclotella and Synedra), respectively contributing 59.7 and $86.5 \%$ of the total biomass ( $\mathrm{mg} \mathrm{L}^{-1}$, as wet weight) in the FILTER treatment, 66.3 and $83.2 \%$ of the total biomass in the CLAD treatment, 33.6 and $94.6 \%$ of the total biomass in the COPE treatment, and 57.2 and $86.6 \%$ of the total biomass in the CONTROL. The biomass of cyanophytes, bacillariophytes, and total phytoplankton significantly increased in every treatment (all $P<0.001$, Fig. 1). However, there was no significant difference among the four treatments. The proportion of chlorophyte biomass (e.g., Ankistrodesmus and Pediastrum) slightly increased in the CLAD treatment (10.8 to $15.5 \%)$ and decreased rapidly from 24.8 to $4.7 \%, 38.3$ to $5.0 \%$, and 36.2 to $7.8 \%$ in the FILTER, COPE, and CONTROL treatments, respectively.

Rotifers were dominated by Keratella (mainly K. cochlearis and K. quadrata) and Brachionus spp., which initially contributed 60.3 and $32.8 \%$ of the total abundance, respectively (Fig. 1). At the end of the experiment, the former increased to 77.2, 87.5, 92.4, and $82.5 \%$ in FILTER, CLAD, COPE, and CONTROL, respectively, while the latter decreased to 5.5, 7.8, 6.3, and $13.1 \%$ in FILTER, CLAD, COPE, and CONTROL, respectively. Both the abundance and biomass of rotifers were significantly different among the four treatments (both $P_{a d j}<0.001$ ). On average, there was significantly higher abundance (94.8 individuals $\mathrm{L}^{-1}$ ) and biomass $\left(73.3 \mu \mathrm{g} \mathrm{L}^{-1}\right)$ in the CONTROL group than in the treatment groups (all $P_{a d j}<0.001$ ).

There was very low abundance of cladocerans and copepods (both 0.1 individuals $\mathrm{L}^{-1}$ ) in the FILTER treatment at the end of the experiment. The final abundance of cladocerans decreased in the CONTROL group, while no obvious change in copepod abundance occurred in the CONTROL group or the COPE treatment. In the CLAD treatment, the abundance of cladocerans 
Table 1. Initial and final abundance of crustacean zooplankton groups in the four treatments

\begin{tabular}{|c|c|c|c|c|c|c|c|c|}
\hline & \multicolumn{4}{|c|}{ Initial abundance (individuals L ${ }^{-1}$ ) } & \multicolumn{4}{|c|}{ Final abundance (individuals $\mathrm{L}^{-1}$ ) } \\
\hline & FILTER & CLAD & COPE & CONTROL & FILTER & CLAD & COPE & CONTROL \\
\hline \multicolumn{9}{|l|}{ Cladocerans } \\
\hline Bosmina sp. & - & 26.0 & - & 25.6 & 0.1 & 5.1 & 1.1 & 10.7 \\
\hline Chydorus ovalis & - & - & - & 3.2 & - & 0.5 & - & - \\
\hline \multicolumn{9}{|l|}{ Copepods } \\
\hline Schmackeria inopinus adults \& larva & - & - & 12.0 & 11.7 & - & 0.7 & 7.2 & 18.0 \\
\hline Limnoithona sinensis adults \& larva & & & - & 4.5 & - & 0.3 & 0.9 & 2.0 \\
\hline Cyclops sp. adults \& larva & - & - & - & 2.0 & 0.1 & 0.5 & 2.5 & 1.8 \\
\hline Copepod nauplii & - & - & & 5.3 & - & 0.2 & 0.4 & 0.8 \\
\hline
\end{tabular}

decreased by the end of the experiment, and few copepods remained in the CLAD treatment (Table 1).

\section{Ciliate community structures}

Ciliate community structures were largely different in the different treatments. By the end of the experiment, the total abundance of ciliates increased in FILTER (from 21.9 to 68.7 cells $\mathrm{mL}^{-1}$ ) and CONTROL (from 21.1 to 31.9 cells $\mathrm{mL}^{-1}$ ) and decreased in CLAD (from 28.3 to 22.5 cells $\mathrm{mL}^{-1}$ ) and COPE (from 16.9 to 13.9 cells $\mathrm{mL}^{-1}$ ). The total ciliate biomass, however, increased in all treatments. In FILTER, CONTROL, CLAD, and COPE, the mean total ciliate abundance was $50.7,33.9,20.8$, and 18.3 cells $\mathrm{mL}^{-1}$, respectively, and mean biomass was $817,599,344$, and $255 \mu \mathrm{g} \mathrm{L} \mathrm{L}^{-1}$ (as wet weight), respectively (Table 2). Removal of crustaceans initiated an increase in ciliate abundance, which was significantly higher in FILTER than in CLAD and COPE (both $P_{a d j}<0.008333$ ). In the CONTROL group containing natural lake water, the ciliate abundance was not significantly lower than the abundance in the FILTER treatment; however, the ciliate abundance in the CONTROL group was higher than the abundances in the other two treatments (CLAD, nonsignificant; COPE, $\left.P_{a d j}<0.008333\right)$. There was a significant interaction between time and treatment for both total abundance $\left(P_{a d j}<0.000167\right)$ and total biomass $\left(P_{a d j}<0.001667\right)$.

A total of 44 ciliate species from 36 genera were observed in this study. Oligotrichs (mainly Rimostrombidium brachykinetum, $R$. hyalinum, and Limnostrombidium viride) and prostomatids (mainly Balanion planctonicum and Urotricha farcta) were the main species in all treatments (Fig. 2). In all containers, abun- dance and biomass of oligotrichs increased, while those of prostomatids decreased by the end of the incubation period. There was no significant difference in oligotrich density, while prostomatid abundance was significantly higher in FILTER and CONTROL than in the other two treatments $\left(P_{a d j}<0.008333\right)$ (Table 2$)$.

In terms of body size, small (biovolume $<3000 \mu \mathrm{m}^{3}$ ) ciliates, including B. planctonicum, Cyrtolophosis mucicola, $R$. brachykinetum, U. farcta, and Cyclidium sp., initially composed most of the total ciliate abundance in all treatments, while medium- (biovolume $3000-5000 \mu \mathrm{m}^{3}$, e.g., $R$. hyalinum) and large-bodied (biovolume $>5000 \mu \mathrm{m}^{3}$, e.g., Askenasia acrostomia, A. chlorelligera, Balantidium pellucidum, Lagynophrya acuminate, and $R$. lacustris) species dominated the ciliate communities at the end of the experiment (Fig. 3). In regard to biomass, large ciliates occupied the majority of the total ciliate biomass from the beginning to the end of the experiment due to their large individual biovolume. Abundance of small ciliates was significantly higher in FILTER than in CLAD and COPE (both $P_{a d j}<0.008333$ ), while abundances of medium and large species showed no significant differences among these three treatments (Table 2). In the CONTROL group, neither total ciliate abundance nor biomass were significantly lower than FILTER; however, both were significantly higher than COPE (both $P_{\text {adj }}<0.008333$ ).

Algivores (e.g., R. Brachykinetum and B. planctonicum) occupied most the total abundance and biomass in the four treatments (Fig. 4). Algivore abundance increased in FILTER and CONTROL and decreased in the other two treatments. There were significant differences in algivore abundance $\left(P_{a d j}<0.008333\right)$, with relatively high values in FILTER $\left(40.5\right.$ cells $\left.\mathrm{mL}^{-1}\right)$ and 
Table 2. Effects of crustacean zooplankton on ciliates (repeated-measures ANOVA, GLM). TREAT $=$ treatment, TIME*TREAT $=$ interaction between time and treatment. Small, medium, and large ciliates refer to ciliate biovolumes of $<3000,3000-5000$, and $>5000 \mu m^{3}$, respectively. $P_{a d j}$ refers to significance level corrected by the Bonferroni technique (Rice 1989). NS, not significant at $P_{a d j}<0.008333$ level

\begin{tabular}{|c|c|c|c|c|c|c|c|}
\hline & \multirow{2}{*}{$\mathrm{F}$} & \multirow{2}{*}{$\mathrm{P}$} & \multirow{2}{*}{$P_{a d j} *$} & \multicolumn{4}{|c|}{ Multiple comparisons results $\% *$} \\
\hline & & & & FILTER & CLAD & COPE & CONTROL \\
\hline \multicolumn{8}{|l|}{ Ciliate abundance } \\
\hline TREAT & 27.23 & 0.0001 & $* * *$ & $50.7^{\mathrm{ad}}$ & $20.8^{\mathrm{bcd}}$ & $18.3^{\mathrm{bc}}$ & $33.9^{\mathrm{abd}}$ \\
\hline TIME & 6.69 & 0.0019 & $*$ & + & - & - & + \\
\hline TIME*TREAT & 7.02 & 0.0001 & $* * *$ & & & & \\
\hline \multicolumn{8}{|l|}{ Ciliate biomass } \\
\hline TREAT & 28.99 & 0.0001 & $* * *$ & $817^{\mathrm{abd}}$ & $344^{\mathrm{abc}}$ & $255^{\mathrm{bc}}$ & $599^{\text {ad }}$ \\
\hline TIME & 89.61 & 0.0000 & $* * *$ & + & + & + & + \\
\hline TIME*TREAT & 5.68 & 0.0003 & $* *$ & & & & \\
\hline \multicolumn{8}{|c|}{ Oligotrich abundance } \\
\hline TREAT & 6.66 & 0.0145 & NS & 32.8 & 12.3 & 13.0 & 20.2 \\
\hline TIME & 40.22 & 0.0000 & $* * *$ & + & + & + & + \\
\hline TIME*TREAT & 7.86 & 0.0000 & $* * *$ & & & & \\
\hline \multicolumn{8}{|l|}{ Oligotrich biomass } \\
\hline TREAT & 22.51 & 0.0003 & $* *$ & $662^{\mathrm{abd}}$ & $276^{\mathrm{abc}}$ & $204^{\mathrm{bc}}$ & $450^{\text {ad }}$ \\
\hline TIME & 110.99 & 0.0000 & $* * *$ & + & + & + & + \\
\hline TIME*TREAT & 3.87 & 0.0038 & $*$ & & & & \\
\hline \multicolumn{8}{|c|}{ Prostomatid abundance } \\
\hline TREAT & 25.94 & 0.0002 & $* *$ & $16.0^{\text {ad }}$ & $6.8^{\mathrm{bc}}$ & $4.6^{\mathrm{bc}}$ & $12.6^{\mathrm{ad}}$ \\
\hline TIME & 66.73 & 0.0000 & $* * *$ & - & - & - & - \\
\hline TIME*TREAT & 11.25 & 0.0031 & $*$ & & & & \\
\hline \multicolumn{8}{|l|}{ Prostomatid biomass } \\
\hline TREAT & 15.01 & 0.0012 & $* *$ & $42^{\text {abd }}$ & $23^{\text {abcd }}$ & $13^{\text {bcd }}$ & $28^{\text {abcd }}$ \\
\hline TIME & 37.11 & 0.0000 & $* * *$ & - & - & - & - \\
\hline TIME*TREAT & 3.16 & 0.0117 & NS & & & & \\
\hline \multicolumn{8}{|c|}{ Small ciliate abundance } \\
\hline TREAT & 12.55 & 0.0022 & $*$ & $35.2^{\mathrm{ad}}$ & $13.8^{\mathrm{bcd}}$ & $13.8^{\mathrm{bcd}}$ & $24.0^{\mathrm{abcd}}$ \\
\hline TIME & 33.40 & 0.0000 & $* * *$ & - & - & - & - \\
\hline TIME*TREAT & 4.33 & 0.0019 & $*$ & & & & \\
\hline \multicolumn{8}{|l|}{ Small ciliate biomass } \\
\hline TREAT & 10.76 & 0.0035 & * & $99^{\mathrm{abd}}$ & $46^{\mathrm{abcd}}$ & $41^{\mathrm{bcd}}$ & $63^{\mathrm{abcd}}$ \\
\hline TIME & 19.83 & 0.0000 & $* * *$ & - & - & - & - \\
\hline TIME*TREAT & 2.92 & 0.0173 & NS & & & & \\
\hline \multicolumn{8}{|c|}{ Medium ciliate abundance } \\
\hline TREAT & 7.63 & 0.0099 & & 5.6 & 2.7 & 1.5 & 1.5 \\
\hline TIME & 176.45 & 0.0000 & $* * *$ & + & + & + & + \\
\hline TIME*TREAT & 2.31 & 0.0495 & NS & & & & \\
\hline \multicolumn{8}{|c|}{ Medium ciliate biomass } \\
\hline TREAT & 8.58 & 0.0070 & * & $28^{\mathrm{ab}}$ & $13^{\mathrm{abcd}}$ & $8^{\mathrm{bcd}}$ & $8^{\mathrm{bcd}}$ \\
\hline TIME & 196.43 & 0.0000 & $* * *$ & + & + & + & + \\
\hline TIME*TREAT & 3.09 & 0.0132 & NS & & & & \\
\hline
\end{tabular}




\begin{tabular}{|c|c|c|c|c|c|c|c|}
\hline \multicolumn{8}{|c|}{ Large ciliate abundance } \\
\hline TREAT & 10.54 & 0.0037 & $*$ & $9.9^{\mathrm{abcd}}$ & $4.3^{\mathrm{abcd}}$ & $3.0^{\mathrm{abc}}$ & $8.4^{\mathrm{abd}}$ \\
\hline TIME & 152.61 & 0.0000 & $* * *$ & + & + & + & + \\
\hline TIME*TREAT & 6.96 & 0.0001 & $* * *$ & & & & \\
\hline \multicolumn{8}{|l|}{ Large ciliate biomass } \\
\hline TREAT & 16.72 & 0.0008 & $* *$ & $690^{\mathrm{abcd}}$ & $284^{\text {abcd }}$ & $206^{\mathrm{abc}}$ & $528^{\text {abd }}$ \\
\hline TIME & 69.14 & 0.0000 & $* * *$ & + & + & + & + \\
\hline TIME*TREAT & 4.02 & 0.0031 & $*$ & & & & \\
\hline \multicolumn{8}{|l|}{ Algivore abundance } \\
\hline TREAT & 12.01 & 0.0025 & * & $40.5^{\text {ad }}$ & $14.0^{\mathrm{bcd}}$ & $14.9^{\text {bcd }}$ & $25.8^{\mathrm{abcd}}$ \\
\hline TIME & 6.74 & 0.0019 & * & + & - & - & + \\
\hline TIME*TREAT & 9.17 & 0.0000 & $* * *$ & & & & \\
\hline \multicolumn{8}{|l|}{ Algivore biomass } \\
\hline TREAT & 12.39 & 0.0022 & $*$ & $524^{\text {abd }}$ & 224 abcd & $176^{\text {bcd }}$ & $279^{\text {abcd }}$ \\
\hline TIME & 27.96 & 0.0000 & $* * *$ & + & + & + & + \\
\hline TIME*TREAT & 2.10 & 0.0708 & NS & & & & \\
\hline \multicolumn{8}{|c|}{ Bacterivore abundance } \\
\hline TREAT & 5.50 & 0.0240 & NS & 6.5 & 5.6 & 2.7 & 3.8 \\
\hline TIME & 0.30 & 0.8265 & NS & + & - & - & - \\
\hline TIME*TREAT & 1.19 & 0.3474 & NS & & & & \\
\hline \multicolumn{8}{|l|}{ Bacterivore biomass } \\
\hline TREAT & 10.06 & 0.0043 & $*$ & $43^{\text {abd }}$ & $38^{\text {abd }}$ & $22^{\mathrm{cd}}$ & 31 abcd \\
\hline TIME & 0.72 & 0.5486 & NS & + & - & - & + \\
\hline TIME*TREAT & 1.90 & 0.1011 & NS & & & & \\
\hline \multicolumn{8}{|c|}{ Mixotroph abundance } \\
\hline TREAT & 12.36 & 0.0023 & $*$ & $3.3^{\mathrm{abcd}}$ & $1.1^{\mathrm{abcd}}$ & $0.6^{\mathrm{abc}}$ & $4.0^{\mathrm{abd}}$ \\
\hline TIME & 38.60 & 0.0003 & $* *$ & + & + & + & + \\
\hline TIME*TREAT & 2.85 & 0.1054 & NS & & & & \\
\hline \multicolumn{8}{|l|}{ Mixotroph biomass } \\
\hline TREAT & 18.27 & 0.0006 & $* *$ & $187^{\mathrm{abcd}}$ & $55^{\text {abcd }}$ & $27^{\mathrm{abc}}$ & $196^{\text {abd }}$ \\
\hline TIME & 85.60 & 0.0000 & $* * *$ & + & + & + & + \\
\hline TIME*TREAT & 4.11 & 0.0027 & $*$ & & & & \\
\hline
\end{tabular}

CONTROL (25.8 cell $\mathrm{mL}^{-1}$ ) and low values in CLAD (14.0 cells $\mathrm{mL}^{-1}$ ) and COPE (14.9 cells $\left.\mathrm{mL}^{-1}\right)$. By the end of the experiment, the composition of the total abundance shifted; in all treatments, the percentage of bacterivores (e.g., U. farcta) decreased, and the percentage of mixotrophs (e.g., L. viride and A. chlorelligera) increased. Together, omnivores (e.g., B. pellucidum, Linostomella vorticella, and Hypotrichidium conicum) and predators (e.g., Actinobolina radians and Litono- tus cygnus) composed less than $1 \%$ of the total ciliate abundance and approximately $10 \%$ of the total biomass in every treatment.

Twelve taxa, each with an abundance greater than 0.1 cells $\mathrm{mL}^{-1}$, composed $99.0 \%$ of the total abundance, including $R$. brachykinetum (average 11.1 cells $\mathrm{mL}^{-1}$, $36.1 \%$ ), B. planctonicum (average 68.2 cells $\mathrm{mL}^{-1}$, $22.1 \%$ ), $U$. farcta (average 3.2 cells $\mathrm{mL}^{-1}, 10.2 \%$ ), $R$. hyalinum (average 2.8 cells $\mathrm{mL}^{-1}, 9.1 \%$ ), R. lacus- 

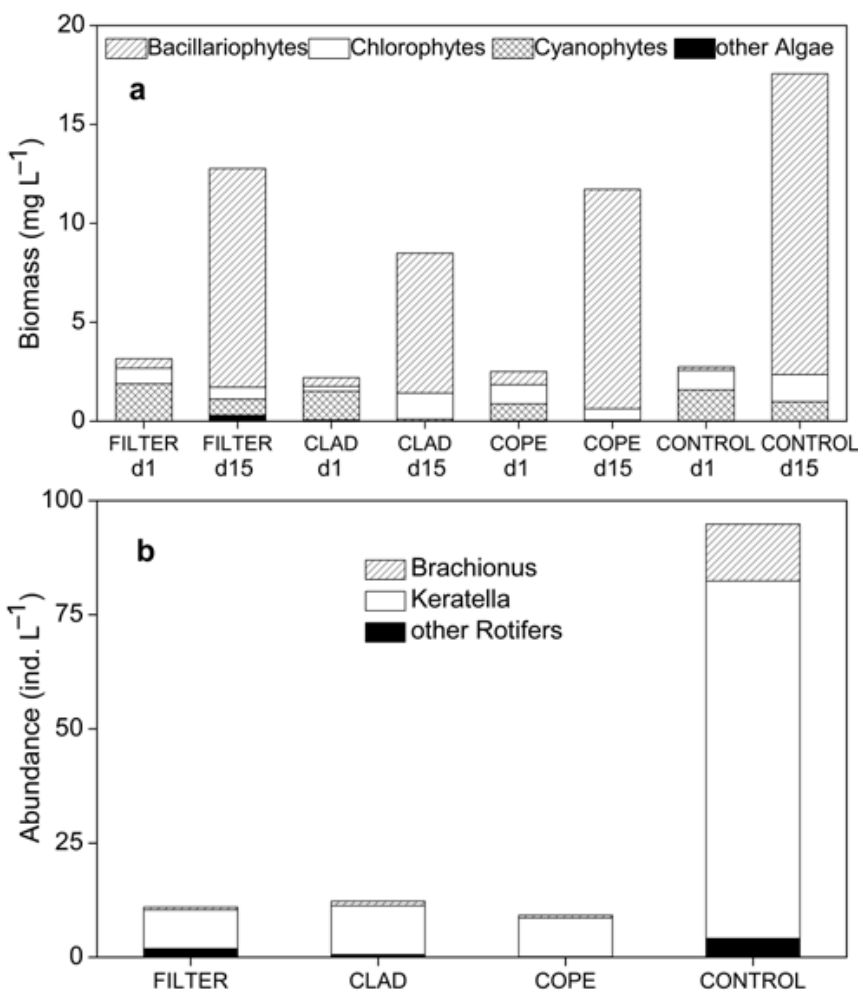

Fig. 1. The initial (d1) and final (d15) biomass of algae (a) and final abundance of rotifers (b) in the four treatments.

tris (average 2.5 cells $\mathrm{mL}^{-1}, 8.2 \%$ ), L. viride (average 2.1 cells $\mathrm{mL}^{-1}, 6.9 \%$ ), Halteria spp. (average 0.8 cells $\mathrm{mL}^{-1}, 2.5 \%$ ), Cyclidium sp. (average 0.6 cells $\mathrm{mL}^{-1}$, $1.8 \%$ ), A. acrostomia (average 0.3 cells $\mathrm{mL}^{-1}, 1.1 \%$ ), Tintinnidium pusillum (average 0.1 cells $\mathrm{mL}^{-1}, 0.4 \%$ ), A. chlorelligera (average 0.1 cells $\mathrm{mL}^{-1}, 0.3 \%$ ), and Vorticella spp. (V. campanula $+V$. aquadulcis complex, average 0.1 cells $\mathrm{mL}^{-1}, 0.3 \%$ ) (Fig. 5). We also found some species that were very common but far less abundant, e.g., B. pellucidum, Codonella cratera, $H$. conicum, L. acuminata, L. vorticella, Pseudostrombidium planctonticum, and Pelagostrombidium mirabile (Fig. 6). With the exception of A. acrostomia and T. pusillum, each species listed above showed a significant temporal change in abundance. Only five species, however, experienced significant changes in abundance among the different treatments (for B. planctonicum, A. chlorelligera, and T. pusillum, $P_{a d j}<0.001667$; for $R$. hyalinum and $L$. viride, $P_{a d j}<0.008333$ ). There was no significant interaction between time and treatment for those five species.

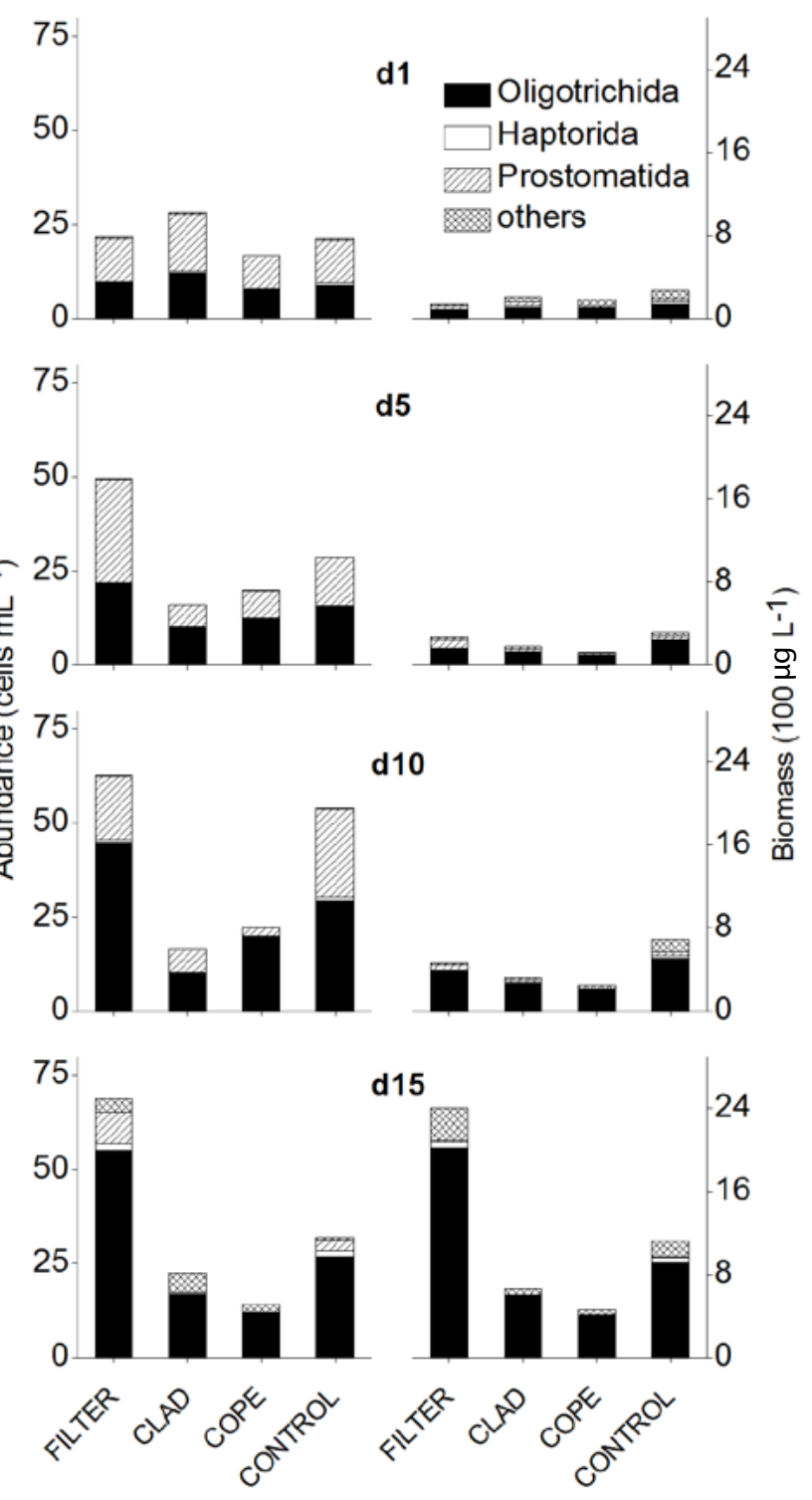

Fig. 2. The abundance and biomass of ciliate taxa in the four treatments. The samples were collected on days $1,5,10$, and 15 .

\section{DISCUSSION}

Our results clearly show that both cladocerans (Bosmina sp.) and copepods (pseudodiaptomid Schmackeria inopinus) had substantial impacts on the abundance, biomass, and winter ciliate community structure in Lake Chaohu, and we highlight the importance of interference and exploitative competition among metazooplankton groups. Total ciliate abundance significantly increased in response to the removal of crustacean 

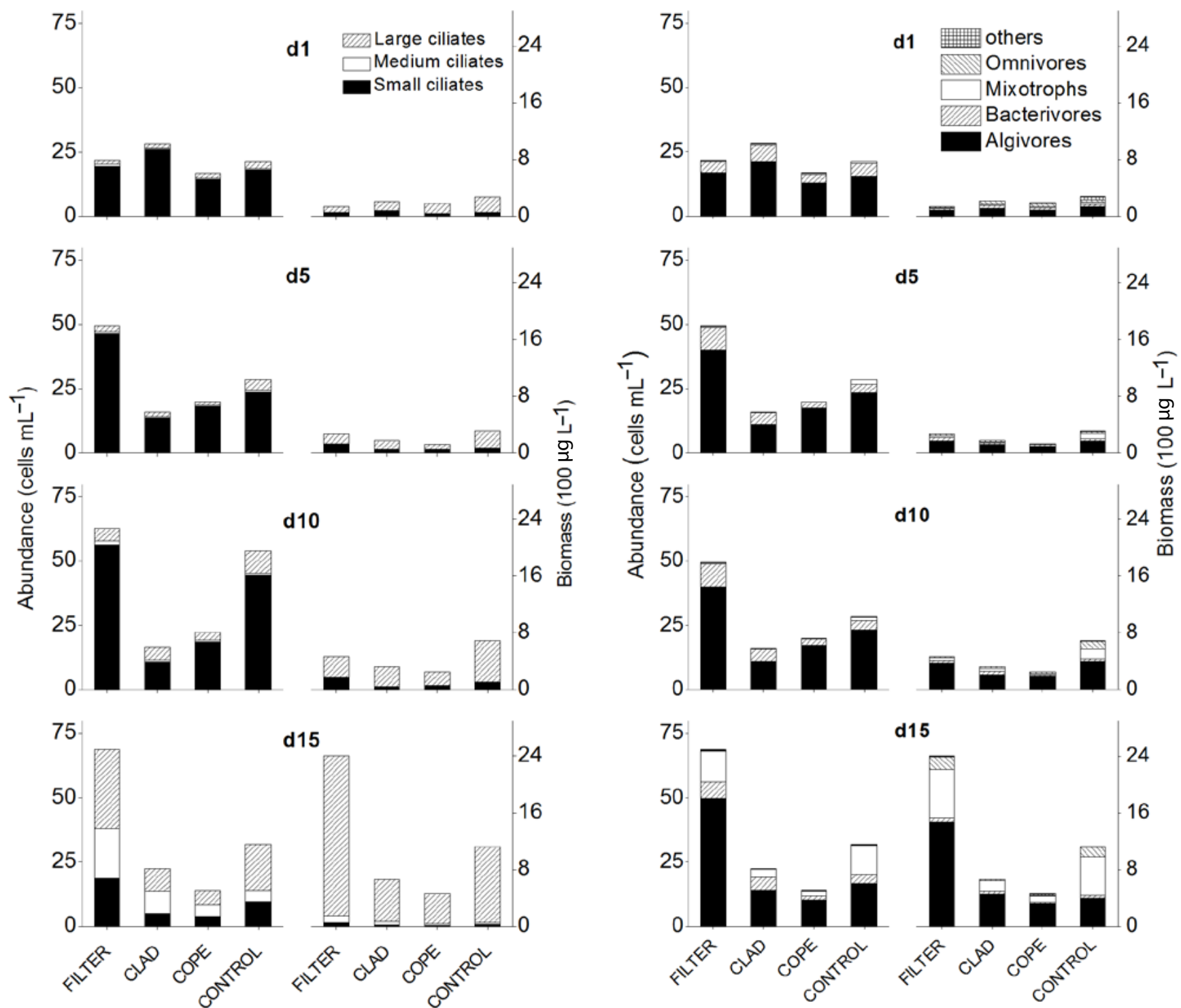

Fig. 3. Ciliate abundance and biomass by classification of body size. Small, medium, and large ciliates refer to a ciliate biovolume of $<3000,3000-5000$, and $>5000 \mu \mathrm{m}^{3}$, respectively.

Fig. 4. Abundance and biomass of ciliate functional feeding groups.

zooplankton, mainly Bosmina sp. and pseudodiaptomid Schmackeria inopinus, while other comparable studies commonly used other crustacean zooplankton species, e.g., Daphnia, cyclopoids, and diaptomids (e.g., Burns and Gilbert 1993; Jürgens 1994; Wiackowski et al. 1994; Wickham 1995; Adrian and Schneider-Olt 1999; Agasild et al. 2013). This study is in line with several other studies, demonstrating that ciliate response is dependent on both the ciliate and crustacean zooplankton species being studied (Jürgens 1994; Wiackowski et al. 1994). Here, the response of ciliates was different

in the presence of copepods (Schmackeria inopinus) compared with cladocerans (Bosmina sp.) and varied among categories including ciliate population, relative body size, and functional feeding groups (Table 2).

The few copepods remaining in the CLAD treatment at the end of the experiment may have been caused by nauplii passing through the plankton net $(64 \mu \mathrm{m})$, and the same mechanism may explain the Bosmina sp. abundance in the COPE treatment (small individuals slipped through the plankton net) and the results of the FILTER treatment. These animals, how- 
ever, composed very small proportions of the total abundance of crustacean zooplankton in the CLAD and COPE treatments. Screening may also remove rotifers (mainly Keratella spp. and Brachionus spp.); thus, there was significantly low rotifer density in the FILTER, CLAD, and COPE treatments. For the small cladocerans, Bosmina sp. always made up more than $89 \%$ of the cladoceran abundance, and the Bosmina sp. impacted the ciliates by suppressing their population. Similarly, the pseudodiaptomid Schmackeria inopinus is believed to be the main contributor to the suppression of ciliates by copepods. This short-term and smallcapacity experimental incubation may overestimate the impacts of crustacean zooplankton on ciliates occurring in lakes over longer spatial scales (Sarnelle 1997). Still, the response of ciliates to the presence and absence of crustacean zooplankton groups can provide extensive information on the interactions between crustacean zooplankton and ciliate trophic levels.

Previous studies have documented that mediumand large-bodied crustaceans (e.g., daphnids) were the most effective grazers that might strongly impact ciliate populations, while small forms (e.g., Bosmina and Chydorus) were challenged by their top-down control on these unicellular heterokaryotic organisms (Gilbert 1989; Wickham and Gilbert 1991; Ventelä et al. 2002). In the present study, we identify the suppression effects of small Bosmina sp. on ciliates based on two pieces of evidence. First, total ciliate abundance decreased in the treatment that only included cladocerans (CLAD), while it increased in the FILTER treatment. Second, the total number of ciliates was significantly higher in FILTER than in CLAD (Table 2). The suppression effects, however, may also depend on the abundance of Bosmina sp. During the incubation period, the total ciliate abundance decreased quickly in the first five days and then increased by a small margin starting on day 10 in the CLAD treatment. This trend was likely caused by the decline in Bosmina sp. abundance, from 26.0 to 5.1 individuals $\mathrm{L}^{-1}$. Suppression impacts of Bosmina on ciliates were also observed in an in situ investigation in Lake Chaohu (Li et al. 2016). The results from this study also suggested that the dominance of Bosmina sp. may contribute to the relatively low ciliate abundance in Lake Chaohu in winter.

The temporal dynamic pattern of ciliate abundance in COPE was different from that in CLAD. In the presence of copepods only, the total abundance of ciliates initially increased slightly and then largely decreased after day 10 , probably because of the change in devel- opmental instar composition of the copepod population. The importance of ciliates as a food resource for copepods has been highlighted by several indoor studies (e.g., Hartmann et al. 1993; Kamjunke et al. 2012; Dhanker et al. 2013), and clear suppression of ciliate populations by copepods, including both cyclopoids (e.g., Cyclops, Diacyclops, and Thermocyclops) and calanoids (e.g., Eudiaptomus and Diaptomus), has been verified in many in situ experiments (e.g., Wiackowski et al. 1994; Adrian and Schneider-Olt 1999; Jürgens et al. 1999; Hansen 2000). This study provides further evidence for strong top-down control effects on ciliates by copepods (mainly pseudodiaptomids Schmackeria inopinus), as we found significantly lower total ciliate abundance and biomass in the treatment containing only copepods (COPE) than in the FILTER treatment. Nevertheless, when cladocerans and copepods were simultaneously abundant, their top-down control on ciliates might have declined, as the total of both ciliate abundance and biomass were lower in CONTROL than in FILTER but were relatively higher than those in CLAD and COPE. This may have been caused by the interference and exploitative competition among the metazoan zooplankton groups (copepods, cladocerans, and rotifers) (Gilbert and MacIsaac 1989; MacIsaac and Gilbert 1991).

Taxonomic replacements occurred in every treatment. Generally, small Balanion planctonicum and Urotricha farcta were replaced by omnivorous - bacteria and picocyanobacterial feeders belonging to Oligotrichida (mainly small Rimostrombidium brachykinetum, medium $R$. hyalinum, and large $R$. lacustris and Limnostrombidium viride); however, they varied in their susceptibility to crustacean zooplankton groups. As shown in Fig. 2, we found a nearly two-fold increase in prostomatid abundance during the first five days after crustacean zooplankton were removed, but prostomatid numbers rapidly decreased by ca. $60 \%$ in CLAD during the first five days and by ca. $70 \%$ in COPE from the fifth to the tenth day. Statistical analysis showed that prostomatid abundance was significantly suppressed by cladocerans (Bosmina sp.) and copepods (Schmackeria inopinus), and this suppression effect significantly interacted with incubation time. Several studies found that suppression effects by crustacean zooplankton were higher on oligotrichs compared with prostomatids and other ciliate species (Hansen 2000; Zöllner et al. 2003). In this study, the total number of oligotrichs was not restrained by crustaceans; however, their biomass was significantly suppressed by copepods, and species replacements occurred within oligotrich ciliates. Final- 

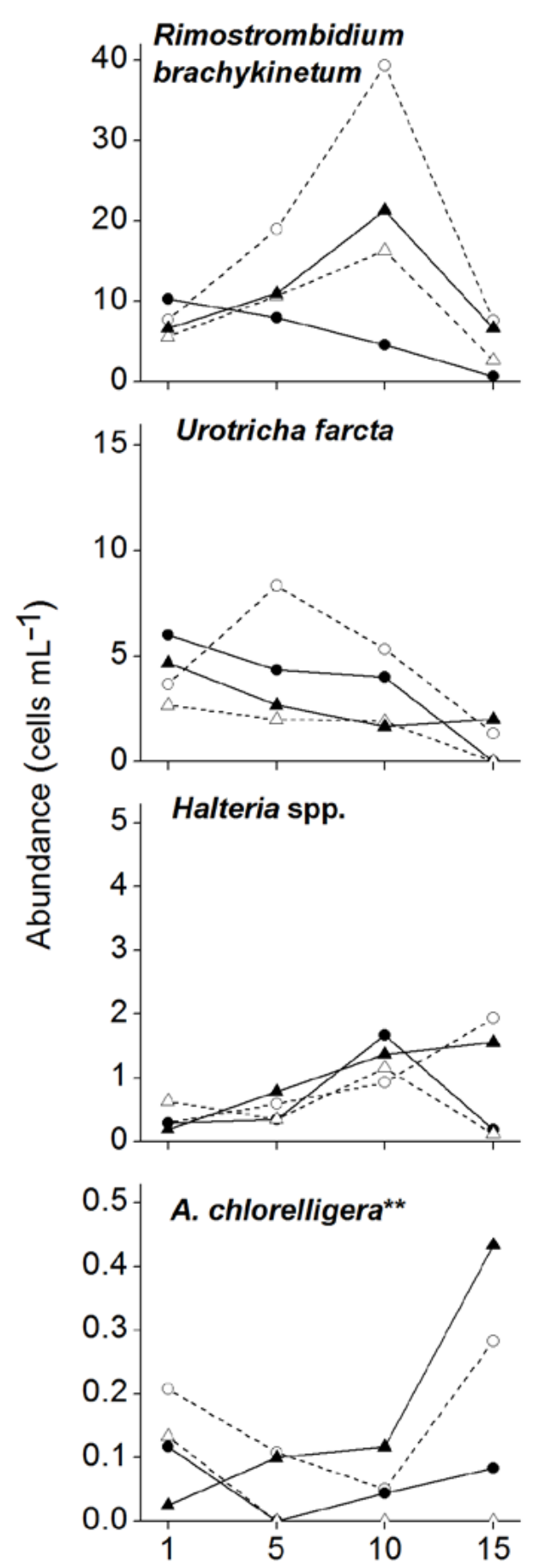
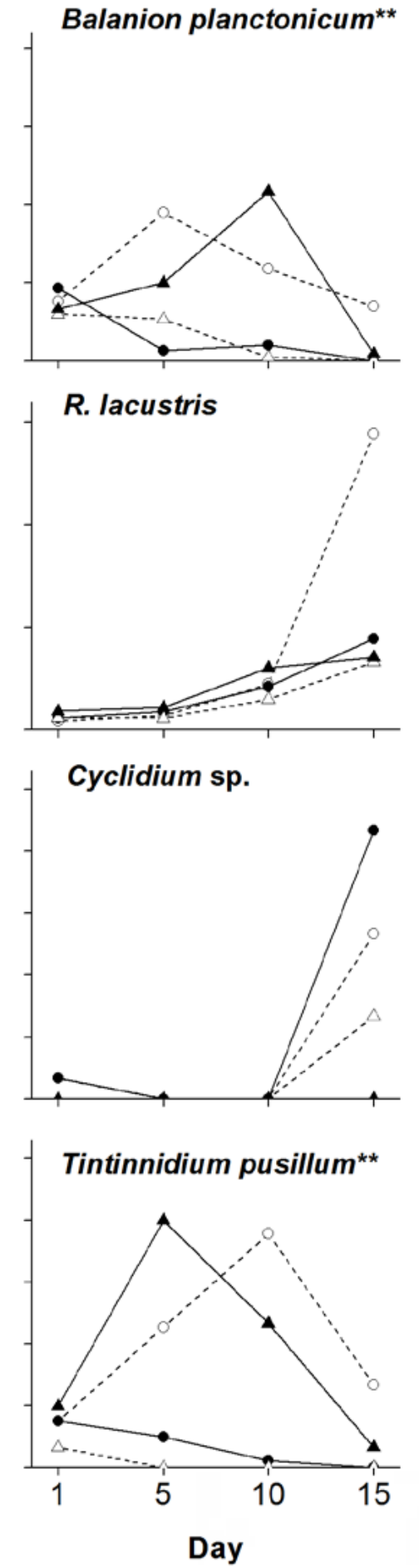

\section{R. hyalinum*}

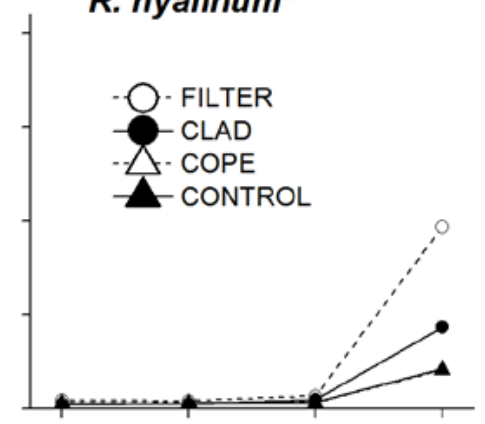

Limnostrombidium viride*

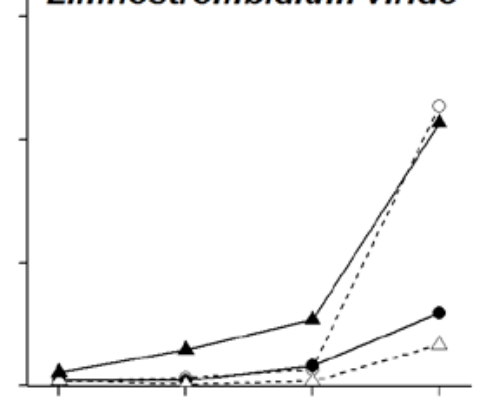

Askenasia acrostomia

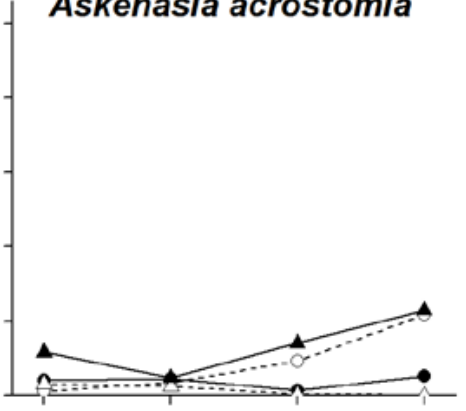

Vorticella spp.

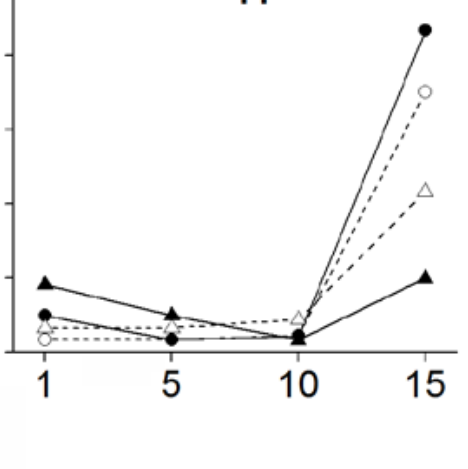

Fig. 5. Dynamics of some dominant ciliate species during the experiment. The samples were collected on days $1,5,10$, and 15 . $* P_{a d j}<0.008333, * * P_{a d j}<0.001667$ 


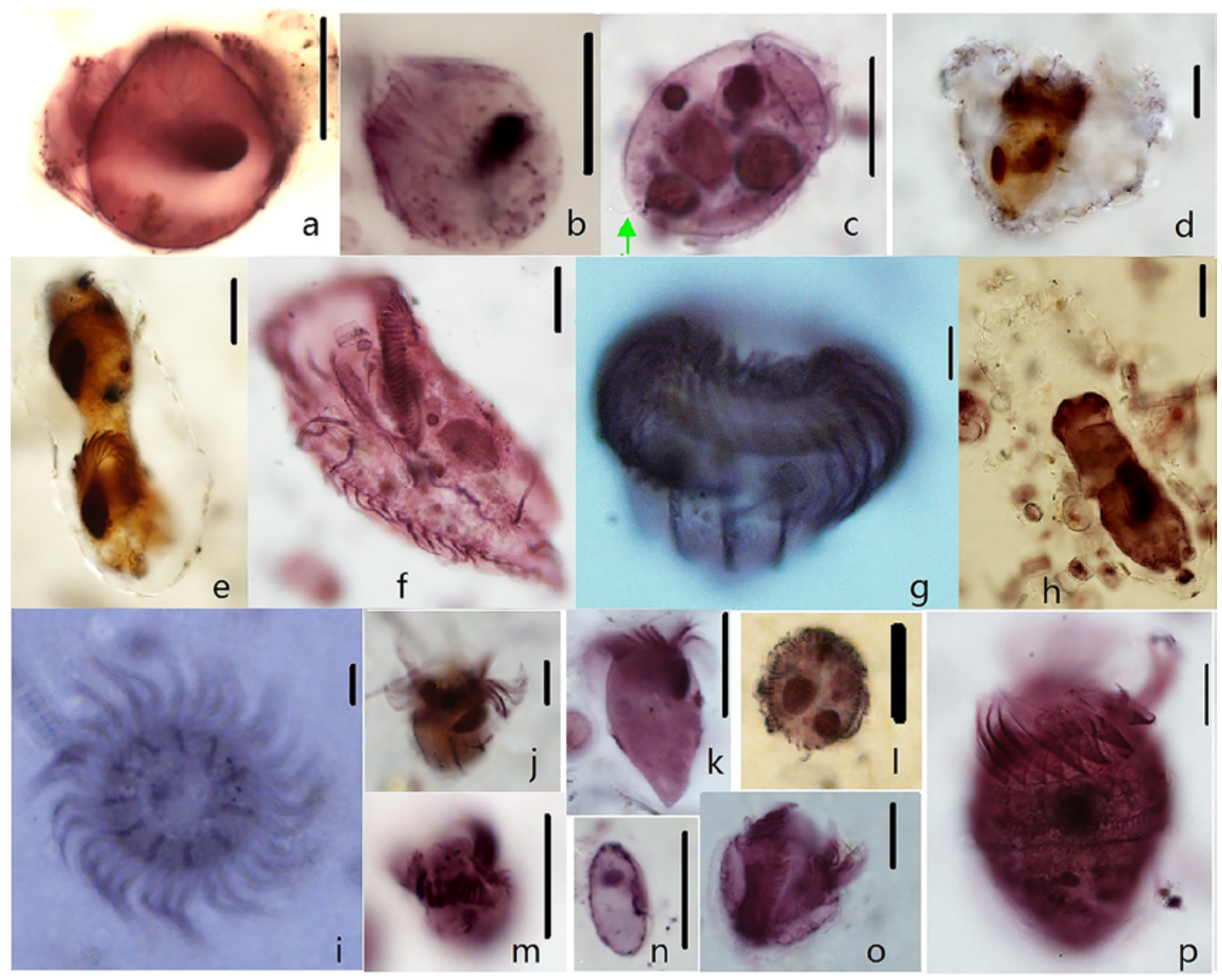

Fig. 6. Microphotographs of some common ciliates stained with the QPS approach during the experiment. (a) Askenasia acrostomia, (b) Askenasia chlorelligera, (c) Balanion planctonicum, (d) and (e) Codonella cratera, (f) Pseudostrombidium planctonticum, (g) and (i) Rimostrombidium lacustris, (h) Tintinnidium pusillum, (j) Rimostrombidium hyalinum, (k) Rimostrombidium brachykinetum, (l) Urotricha farcta, (m) Halteria sp., (n) Cyclidium sp., (o) Pelagostrombidium mirabile, (p) Limnostrombidium viride. All photographs were taken with an Olympic DP73 digital camera mounted on an Olympic BX51 light microscope. Scale bar equals $10 \mu \mathrm{m}$.

ly, predominant small $R$. brachykinetum decreased, and medium-bodied $R$. hyalinum and large-bodied $R$. lacustris and $L$. viride dominated the oligotrich ciliates.

At the community level, both small $(<14.4 \mu \mathrm{m}$ of equivalent spherical diameter) and medium (14.4$17.1 \mu \mathrm{m}$ of equivalent spherical diameter) ciliates were clearly affected by copepods, while cladocerans only suppressed small ciliates (Table 2). This may be a result of particle selection in the crustacean zooplankton feeding process (Barnett et al. 2007). Functional feeding groups, especially algivores, were also strongly affected by both cladocerans and copepods. Algal food competition between ciliates and crustaceans may have induced the significantly lower abundance of algivore ciliates in CLAD (e.g., R. brachykinetum) and COPE (e.g., B. planctonicum) than that seen in FILTER (Car- rick et al. 1991; Agasild et al. 2007). The decrease in bacterivore (e.g., U. farcta) abundance percentage in every treatment may have also been caused by the reduced food resources available in containers than those found in natural lake water, in addition to the suppression effect induced by copepods.

In conclusion, we have verified that both cladocerans (Bosmina sp.) and copepods (pseudodiaptomid Schmackeria inopinus) had substantial impacts on winter ciliate abundance, biomass, and community structure in Lake Chaohu, and we highlight the importance of interference and exploitative competition among metazooplankton groups. The removal of crustacean zooplankton, mainly Bosmina sp. and pseudodiaptomid Schmackeria inopinus, initiated a significant increase in ciliate abundance during the incubation period. Pros- 
tomatid abundance was significantly suppressed by both cladocerans and copepods, and this suppression effect significantly interacted with incubation time. Oligotrich abundance was not restrained by crustacean groups, but their biomass was strongly impacted by copepods; moreover, taxonomic replacements occurred within these species. In terms of body size, both small and large ciliates were strongly suppressed by copepods, while the suppression effect of cladocerans only affected small ciliates. In contrast to bacterivores and other functional feeding groups, algivores were strongly affected by both cladocerans and copepods.

Acknowledgments. Funding for this project was provided by the National Natural Science Foundation of China (No. 31400398), the Natural Science Foundation of Anhui Province (No. 1508085QC55), the Provincial Science and Technology Projects Program of Anhui (No. 1604a0802111), and the China Agriculture Research System (CARS-46). Field work was performed with assistance from Fishery Management of Lake Chaohu.

\section{REFERENCES}

Adrian R., Schneider-Olt B. (1999) Top-down effects of crustacean zooplankton on pelagic microorganisms in a mesotrophic lake. J. Plankton Res. 21: 2175-2190

Agasild H., Zingel P., Karus K., Kangro K., Salujõe J., Nõges T. (2013) Does metazooplankton regulate the ciliate community in a shallow eutrophic lake? Freshw. Biol. 58: 183-191

Agasild H., Zingel P., Nõges T. (2012) Live labeling technique reveals contrasting role of crustacean predation on microbial loop in two large shallow lakes. Hydrobiologia 684: 177-187

Agasild H., Zingel P., Tõnno I., Haberman J., Nõges T. (2007) Contribution of different zooplankton groups in grazing on phytoplankton in shallow eutrophic Lake Võrtsjärv (Estonia). Hydrobiologia 584: 167-177

Balseiro E. G., Modenutti B. E., Queimaliños C. P. (2001) Feeding of Boeckella gracilipes (Copepoda, Calanoida) on ciliates and phytoflagellates in an ultraoligotrophic Andean lake. J. Plankton Res. 23: 849-857

Barnett A. J., Finly K., Beisner B. E. (2007) Functional diversity of crustacean zooplankton communities: towards a trait-based classification. Freshw. Biol. 52: 796-813

Burns C. W., Gilbert J. J. (1993) Predation on ciliates by freshwater calanoid copepods: rates of predation and relative vulnerabilities of prey. Freshw. Biol. 30: 377-393

Burns C. W., Schallenberg M. (1996) Relative impacts of copepods, cladocerans and nutrients on the microbial food webs of a mesotrophic lake. J. Plankton Res. 18: 683-714

Burns C. W., Schallenberg M. (2001) Calanoid copepods versus cladocerans: Consumer effects on protozoa in lakes of different trophic status. Limnol. Oceanogr. 46: 1558-1565

Carrick H. J., Fahnenstiel G. L., Stoermer E. F., Wetzel R. G. (1991) The importance of zooplankton-protozoan trophic couplings in Lake Michigan. Limnol. Oceanogr. 36: 1335-1345

Chiang S. C., Du N. S. (1979) Fauna Sinica, Crustacea, Freshwater Cladocera. Science Press, Academia Sinica, Beijing

Corliss J. O. (1979) The ciliated protozoa: characterization, classification, and guide to the literature (2nd ed.). Pergamom, Oxford
Deng D. G., Xie P., Zhou Q., Yang H., Guo L. G. (2007) Studies on temporal and spatial variations of phytoplankton in Lake Chaohu. J. Integr. Plant Biol. 49: 409-418

Deng D. G., Xie P., Zhou Q., Yang H., Guo L. G., Geng H. (2008) Field and experimental studies on the combined impacts of cyanobacterial blooms and small algae on crustacean zooplankton in a large, eutrophic, subtropical, Chinese lake. Limnology 9: $1-11$

Dhanker R., Kumar R., Tseng L. C., Hwang J. S. (2013) Ciliate (Euplotes sp.) predation by Pseudodiaptomus annandalei (Copepoda: Calanoida) and the effects of mono-algal and pluri-algal diets. Zool. Stud. 52: 34

Foissner W., Berger, H. (1996) A user-friendly guide to the ciliates (Protozoa, Ciliophora) commonly used by hydrobiologists as bioindicators in rivers, lakes, and waste waters, with notes on their ecology. Freshw. Biol. 35: 375-482

Foissner W., Berger H., Schaumburg J. (1999) Identification and ecology of limnetic plankton ciliates. Informationsberichte des Bayer. Landesamtes für Wasserwirtschaft, Heft

Galbraith L. M., Burns C.W. (2010). Drivers of ciliates and phytoplankton community structure across a range of water bodies in southern New Zealand. J. Plankton Res. 32: 327-339

Gilbert J. J. (1989) The effect of Daphnia interference on a natural rotifer and ciliate community short-term bottle experiments. Limnol. Oceanogr. 34: 606-617

Gilbert J. J., MacIsaac H. J. (1989) The susceptiblity of Keratella cochlearis to interference from small cladocerans. Freshw. Biol. 22: 333-339

Hansen A. (2000) Response of ciliates and Cryptomonas to the spring cohort of a cyclopoid copepod in a shallow hypereutrophic lake. J. Plankton Res. 22: 185-203

Hartmann H. J., Taleb H., Aleya L., Lair N. (1993) Predation on ciliates by the suspension-feeding calanoid copepod Acanthodiaptomus denticornis. Can. J. Fish. Aquat. Sci. 50: 1382-1393

Hu H. J., Wei Y. X. (2006) The freshwater algae of China: systematics, taxonomy and ecology. Science Press, Beijing

Huang X., Chen W.M., Cai Q.M. (2000). Survey, observation and analysis of lake ecology. Standards Press of China, Beijing

Jack J. D., Gilbert J. J. (1993) Susceptibilities of different-sized ciliates to direct suppression by small and large cladocerans. Freshw. Biol. 29: 19-29

Jack J. D., Gilbert J. J. (1997) Effects of metazoan predators on ciliates in freshwater plankton communities. J. Eukaryot. Microbiol. 44: 194-199

Jürgens K. (1994) Impact of Daphnia on planktonic microbial food webs - A review. Mar. Microb. Food Webs 8: 295-324

Jürgens K., Skibbe O., Jeppesen E. (1999) Impact of metazooplankton on the composition and population dynamics of planktonic ciliates in a shallow, hypereutrophic lake. Aquat. Microb. Ecol. 17: $61-75$

Kahl A. (1930-1935) Urtiere order protozoa. I: Wimpertiere order Ciliata (Infusoria). In: Dahl, F., Die Tierwelt Deutschlands. Verlag von Gustav Fischer, Jena

Kamjunke N., Kramps M., Chavez S., Woelfl S. (2012) Consumption of large, Chlorella-bearing ciliates (Stentor) by Mesocyclops araucanus in North Patagonian lakes. J. Plankton Res. 34: 922-927

Li J., Chen F. Z., Liu Z. W., Xu K. D., Zhao B. Y. (2013) Compositional differences among planktonic ciliate communities in four subtropical eutrophic lakes in China. Limnology 14: 105-116

Li J., Chen F. Z., Liu Z. W., Zhao X. X., Yang K., Lu W. X., Cui K. (2016) Bottom-up versus top-down effects on ciliate com- 
munity composition in four eutrophic lakes (China). Eur. J. Protistol. 53: $20-30$

Li J., Dai X., Sun Y., Shu T. T., Liu Z. W., Chen F. Z, Lu W. X. (2014) Community structure of planktonic ciliates and its relationship to environmental variables in Lake Taihu. Acta Ecol. Sin. 34: $4672-4681$

Lynn D. H. (2008) The ciliated protozoa: characterization, classification, and guide to the literature (3rd ed.). Springer, Berlin

MacIsaac H. J., Gilbert J. J. (1991) Competition between Keratella cochlearis and Daphnia ambigua: effects of temporal patterns of food supply. Freshw. Biol. 25: 189-198

Rice W. R. (1989) Analyzing tables of statistical tests. Evolution 43: $223-225$

Rollwagen-Bollens G., Bollens S. M., Gonzalez A., Zimmerman J., Lee T., Emerson J. (2013) Feeding dynamics of the copepod Diacyclops thomasi before, during and following filamentous cyanobacteria blooms in a large, shallow temperate lake. $\mathrm{Hy}$ drobiologia 705: 101-118

Sanders R. W., Wickham S. A. (1993) Planktonic protozoa and metazoa: predation, food quality and population control. Mar. Microb. Food Webs 7: 197-223

Sarnelle O. (1997) Daphnia effects on microzooplankton: comparisons of enclosure and whole-lake responses. Ecology 78: 913-928

Sheng J. R. (1979) Fauna Sinica, Crustacea, Freshwater Copepoda. Science Press, Academia Sinica, Beijing

Skibbe O. (1994) An improved quantitative protargol stain for ciliates and other planktonic protists. Arch. Hydrobiol. 130: 339 347

van Wichelen J., Johansson L. S., Vanormelingen P., Declerck S. A. J., Lauridsen T. L., de Meester L., Jeppesen E., Vyverman W. (2013) Planktonic ciliate community structure in shallow lakes of lowland Western Europe. Eur. J. Protistol. 49: 538-551

Ventelä A.-M., Wiackowski K., Moilanen M., Saarikari V., Vuorio K., Sarvala J. (2002). The effect of small zooplankton on the microbial loop and edible algae during a cyanobacterial bloom. Freshw. Biol. 47: 1807-1819
Wang J. J. (1961) Fauna Sinica, Rotifer. Science Press, Academia Sinica, Beijing

Weisse T., Scheffel-Möser U. (1990) Growth and grazing loss rates in single-celled Phaeocystis sp. (Prymnesiophyceae). Mar. Biol. 106: $153-158$

Wiackowski K., Breet M. T., Goldman C. (1994) Differential effects of zooplankton species on ciliate community structure. Limnol. Oceanogr. 39: 486-492

Wickham S. A. (1995) Trophic relations between cyclopoid copepods and ciliated protists: Complex interactions link the microbial and classic food webs. Limnol. Oceanogr. 40: 1173-1181

Wickham S. A. (1998) The direct and indirect impact of Daphnia and Cyclops on a freshwater food web. J. Plankton Res. 20: 739-755

Wickham S. A., Gilbert J. J. (1991) Relative vulnerabilities of natural rotifer and ciliate communities to cladocerans: laboratory and field experiments. Freshw. Biol. 26: 77-86

Zingel P., Agasild H., Karus K., Kangro K., Tammert H., Tõnno I., Feldmann T., Nõges T. (2016) The influence of zooplankton enrichment on the microbial loop in a shallow, eutrophic lake. Eur. J. Protistol. 52: 22-35

Zubkov M. V., Leakey R. J. G. (2009) Evaluation of the efficiency of metabolism of dinoflagellate phosphorus and carbon by a planktonic ciliate. Eur. J. Protistol. 45: 166-173

Zöllner E., Hoppe H., Sommer U., Jürgens K. (2009) Effect of zooplankton-mediated trophic cascades on marine microbial food web components (bacteria, nanoflagellates, ciliates). Limnol. Oceanogr. 54: 262-275

Zöllner E., Santer B., Boersma M., Hoppe H., Jürgens K. (2003) Cascading predation effects of Daphnia and copepods on microbial food web components. Freshw. Biol. 48: 2174-2193

Received on $22^{\text {nd }}$ October, 2017; revised on $18^{\text {th }}$ December, 2017; accepted on $27^{\text {th }}$ December, 2017 